\title{
Exploration of University Education Model Reform Based on the Integration of CDIO and TPACK
}

\author{
Fengmei Xin ${ }^{1, *}$ \\ ${ }^{1}$ College of Modern Manufacturing Engineering, HeiLongJiang University of Technology, Jixi, Heilongjiang 158100, \\ China \\ *Corresponding author. Email: 18245904309@163.com
}

\begin{abstract}
Aiming at the problems of insufficient innovation ability and insufficient integration of information technology and curriculum teaching in China, a university education model based on the integration of CDIO and Technological Pedagogical Content Knowledge is proposed. CDIO theory attaches importance to engineering practice and Technological Pedagogical Content Knowledge theory emphasizes the theoretical basis of teachers. This model combines the advantages of both and fully integrates the needs of teachers and students. This paper expounds on the components and topological structure of the new university education model, and puts forward the corresponding strategies according to the bottleneck of university education. It has laid a theoretical and practical basis for the further development of university education.
\end{abstract}

Keywords: CDIO theory, TPACK theory, technology teaching, teaching ability

\section{INTRODUCTION}

The Central Committee of the Communist Party of China (CPC) has made it clear that China's education will become a powerful country in terms of education modernization. Promote China to become a learning power, human resources power and talent power. It will lay a solid foundation for building a prosperous, strong, democratic, civilized, harmonious and beautiful modern socialist country by the middle of this century[1]. With the continuous deepening of national education, China's education has entered a new era of integration and innovation and intelligent guidance. However, the problems of the insufficient innovation ability of information technology teaching, insufficient integration of information technology and curriculum teaching and the requirements of education modernization are still more prominent.

In view of the above problems, Hu et al. [2] elaborated on the opportunities and challenges brought by 'Internet +' to Chinese education. Modern education should break through the traditional education model, but not subvert the essence of traditional education. Many scholars have studied and explored folk art[3], high school English[4], and elementary school Chinese[5] based on TPACK theory. Li [6] pointed out that STEM education is in line with China's national conditions. In-depth research can be entered into the three aspects of research objects, research methods and research topics to further promote the development of STEM education research and practice, and improve the level of STEM education research in China. The introduction of the system and the reform of teaching theory are mostly aimed at the teachers' teaching and curriculum planning ability, but do not really achieve the integration of teachers and students. There are many theoretical courses for students and a few practical courses, short learning tasks for ability training courses, and other issues that our current education should pay the most attention to. The unilateral cultivation of students' interest and there is no targeted consultation on the strengths of students.

In order to balance the development of teachers' and students' abilities, this paper puts forward the reform scheme of university education model based on the integration of CDIO and TPACK, and dissects and analyzes its structure and connotation.

\section{CDIO THEORY}

Due to the new education model CDIO proposed by MIT and Royal Swedish Institute of Technology, China is also trying to carry out corresponding learning and Reform Based on this teaching reform experience[7]. CDIO stands for Conceive, Design, Implement and Operate. It takes the life cycle from product development to product operation as the carrier, allowing students to be proactive, practical, and organically connected between courses way to learn engineering. Combining the cultivation of knowledge and ability, integrating theory, practice and innovation, is a new educational concept and talent training mode. Chen et al. [8] established an evaluation index system based on CDIO mode from the perspective of problem traction, basic cross, practice oriented and curriculum driven. As shown in Fig. 1, we are more prepared to locate the connotation and structure contained in CDIO. This theory has been applied to mechanical manufacturing [9], network security [10], automatic control [11], military operations research [12] and other courses. 


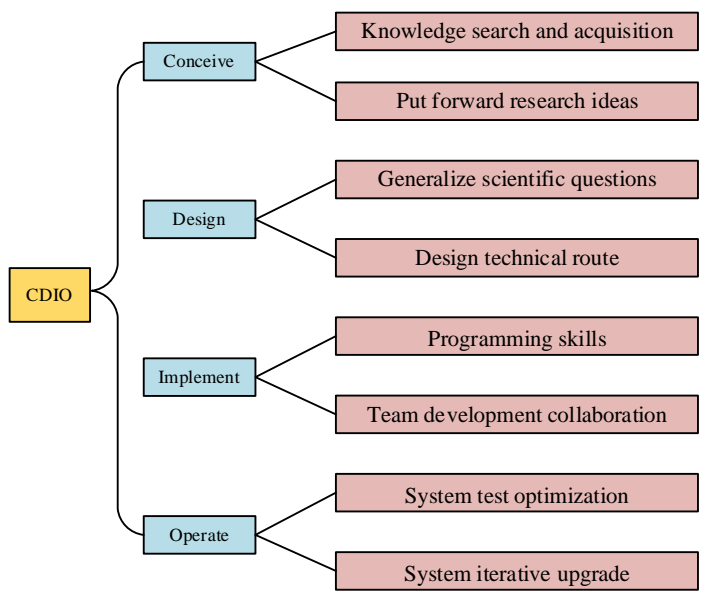

Figure 1. Evaluation index system based on CDIO model

\section{TPACK THEORY}

TPACK (Technological Pedagogical Content Knowledge) was further studied by Koehler and Mishra [13] under the

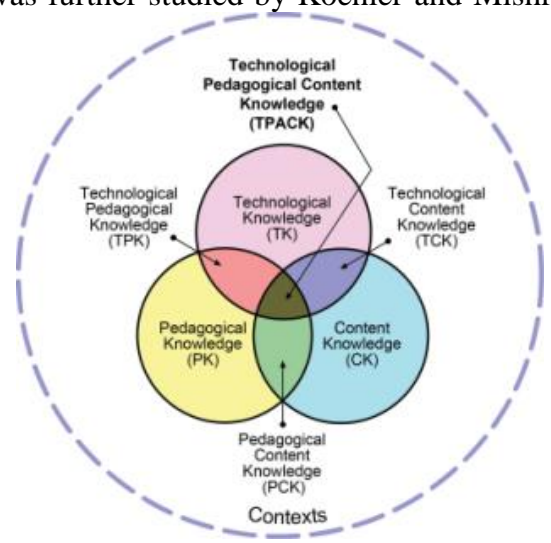

(a) Classification(image from http://tpack.org) framework of Shulman's [14] subject teaching knowledge (PCK). It is mainly divided into three core elements and four composite elements. The specific classification and composition are shown in Fig. 2.

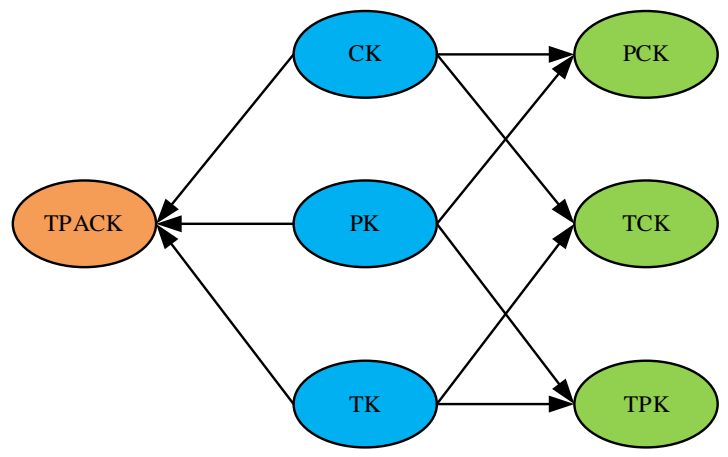

(b) Structural model[15]

Figure 2. TPACK framework with seven knowledge components

\section{INTEGRATED EDUCATION MODEL BASED ON CDIO AND TPACK}

CDIO theory is a kind of engineering education concept, which focuses on process practice, team cooperation and the cultivation of engineering ability. TPACK theory emphasizes the importance of technology for teachers' education and teaching, which is an important theoretical basis for teachers' professional development in the new era. CDIO theory attaches importance to engineering practice. TPACK theory emphasizes the theoretical basis of teachers. However, overemphasizing any aspect will lead to the abnormal development of education. In order to promote the balanced development of education, this paper puts forward the education model based on the concept of CDIO and TPACK. The topological results are shown in Fig. 3, and the specific meaning is shown in Table 1. 


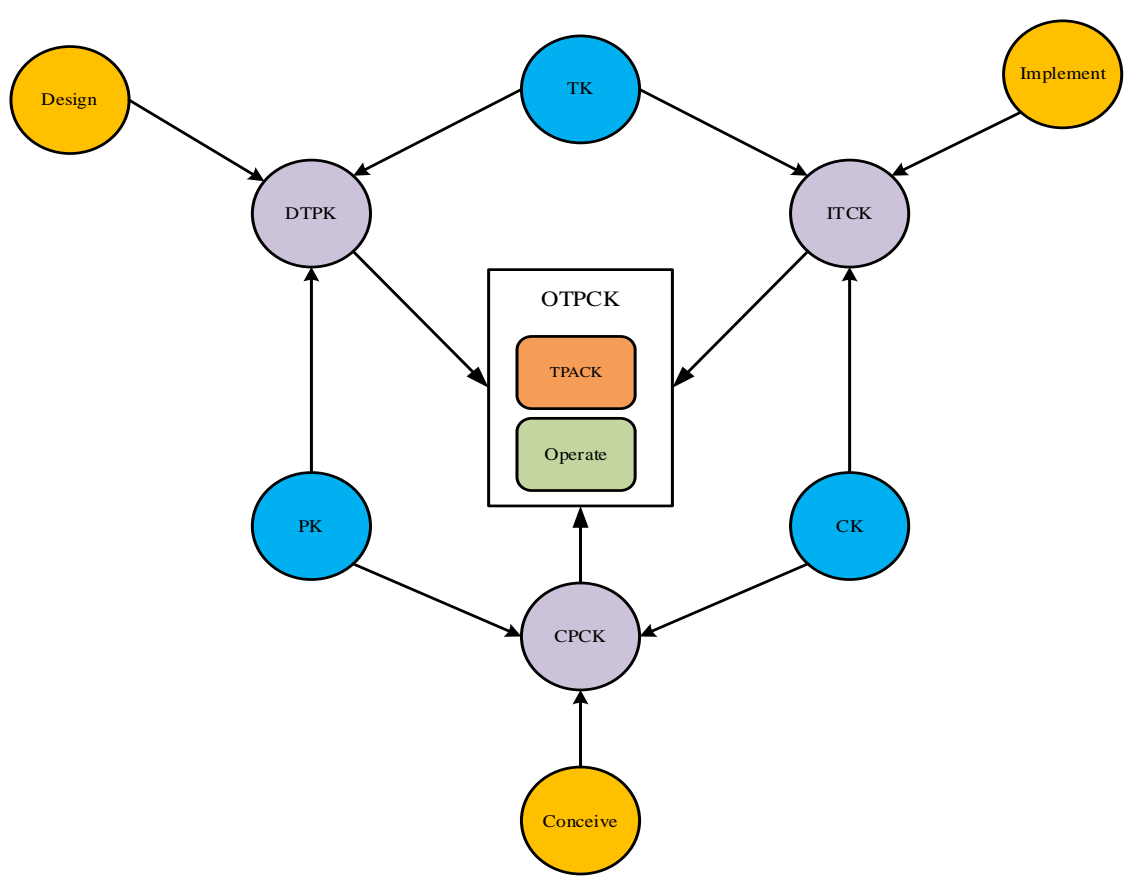

Figure 3. Topological structure of integrated education model

Table 1 The main components of integrated education model based on CDIO and TPACK

\begin{tabular}{|c|l|l|l|}
\hline No. & Aspect & Main Components & Connotation \\
\hline 1 & CPCK & Conceive, PK, CK & $\begin{array}{l}\text { Students have the ability to search for knowledge and put forward research } \\
\text { ideas for problems. Teachers should have a systematic framework for the } \\
\text { knowledge they teach, and cultivate students' active behavior of } \\
\text { autonomous learning and thinking expansion. }\end{array}$ \\
\hline 2 & DTPK & Design, PK, TK & $\begin{array}{l}\text { Design the technical route in line with the law of students' learning, } \\
\text { teachers use practical experience, teaching resources, the Internet to reform } \\
\text { teaching thinking. }\end{array}$ \\
\hline 3 & ITCK & Implement, TK, CK & $\begin{array}{l}\text { In the wisdom development of student team, teachers use specific } \\
\text { technology to stimulate students' potential. }\end{array}$ \\
\hline 4 & OTPCK & Operate, TPACK & $\begin{array}{l}\text { Understand students' prior knowledge and cognitive theory, combined with } \\
\text { operational ability, effectively match students' thinking and teachers' } \\
\text { teaching ability, make learning and ability think through; integrate various } \\
\text { elements to promote students' understanding and knowledge construction. }\end{array}$ \\
\hline
\end{tabular}

China adopts the teaching method of cracking duck and passive, which makes Chinese education appear in a state where students can only learn but cannot think. And now there is multi-disciplinary integration in technology. How to use the education model based on CDIO and TPACK to improve education ability, the following suggestions are put forward:

(1) Comprehensive aspects of problem traction and training objectives

The development of study habits at the undergraduate level is more caused by the curriculum system of the training syllabus, but it lacks in response to the real needs of students. CPCK suggests that teachers should consider scientific and cultural literacy, ability and post when designing syllabus and training programs. Let students self-development, experience the cooperation ability of student groups, fully cultivate students' rational thinking and practical application ability.

(2) Teaching plan and multidisciplinary integration

The goal of curriculum education is to cultivate students' cognitive ability and the application of multi learning knowledge. The problems in reality are related to the integration of multi-disciplinary technologies. DTPK emphasizes the high degree of cross application of design and information technology, so the formulation of teaching plan needs to combine the characteristics of this major to build a multi-disciplinary theoretical system to form a comprehensive understanding of students' thinking expansion. 
(3) Aspects of practical ability training

In class practice teaching should be student-centered, encourage independent teams and independent consultation. The importance of implementation is given in ITCK. The knowledge learned is transformed into the ability to solve problems. After reasonable cooperation and division of labor, the perfect realization of knowledge transfer is completed.

(4) Subject research and teaching evaluation

Discipline establishment is a bridge from theory to practice. OTPCK level combined with operational ability perfectly reflects the positioning of students and teachers in education, focusing on the cultivation of students' ability to understand problems, the practical ability of engineering application, and students' group cooperation ability. It can really effectively match the students' thinking and teachers' teaching ability. To improve the teaching evaluation mechanism, students' ability and teachers' teaching success cannot be evaluated unilaterally by students' achievements. Instead, the evaluation index system of students' ability should be established based on OTPCK.

\section{CONCLUSION}

On the basis of TPACK and combined with CDIO theory, this paper puts forward an integrated education model based on CDIO and TPACK. To avoid the abnormal development of education by only stressing the theoretical role of teachers, and to explain the important components and framework of the new education model. In view of the current educational difficulties, this paper gives a solution based on the new framework, which provides a theoretical basis for the further development of education.

\section{ACKNOWLEDGMENT}

This work was supported by Education and teaching reform project of HeiLongJiang University of Technology.

\section{REFERENCES}

[1] Liu Changyan. Accelerating the Modernization of Education and Embarking on a New Journey to Build a Strong Country for Education-An Interpretation of China's Modernization of Education 2035. Educational Research, vol.40, No.11, 2019, pp.4-16.

[2] Hu Lele. Research on the Opportunities and Challenges of the Internet Plus Brings to China's Education. Modern Educational Technology, 2015, 25(12), pp. 26-32. DOI: 10.3969/j.issn. 1009 8097.2015. 12.004

[3] X. Huifeng. An Ethnic and Folk Art Space Course based on TPACK, in International Journal of Emerging
Technologies in Learning (iJET), vol. 14, pp. 110-121, 2019. DOI:10.3991/ijet. v14i03. 10101.

[4] R. Na, H. Zhang, Y. Wang, Y. Wang, T. Yoneda and Z. Li, "A Study of TPACK Structure of Outstanding English Teacher, " 2017 International Conference of Educational Innovation through Technology (EITT), Osaka, pp. 299-302, 2017. DOI: 10.1109/EITT.2017.78.

[5] N. Zhao, H. Zhang, Y. Wang and Z. Li, "A Case Study of Analysis on TPACK Structure of Teachers in Primary School in China, " 2017 International Conference of Educational Innovation through Technology (EITT), Osaka, 2017, pp. 18-21, DOI: 10.1109/EITT.2017.13.

[6] LI Yeping, WANG Ke, XIAO Yu. Exploring the Status and Development Trends of STEM Education Research: A Review of ResearchArticles Published in Selected Journals between 2000 and 2018. Journal of Mathematics Education, 2019, 28(03): pp. 45-52.

[7] Bai Jianfeng, Lei Hu, Yanfen Li, et al, The Progress of CDIO Engineering Education Reform in Several China Universities: A Review, in Procedia - Social and Behavioral Sciences, vol. 93, 2013, pp.381-385. DOI: https://doi.org/ 10.1016/ j.sbspro. 2013.09.207.

[8] Chen Bin, Xie Xu, Xie Weihao, et al, Exploration of postgraduate project setting based on CDIO model, in Journal of Higher Education, vol.28, 2020, pp.82-85.

[9] Liang Z, Deng H, Tao J. Teaching Examples and Pedagogy of Mechanical Manufacture based on the CDIO-Based Teaching Method. Procedia Engineering, 2011, 15:pp. 4084-4088.

DOI:10.1016/j.proeng.2011.08.766

[10] Feng Yu, Yinghua Wang, Preliminary Investigation on CDIO Incorporated Educational Reform of the Course of Network Security, IERI Procedia, 2012, 2: pp.346-349. DOI: https:// doi.org/ 10.1016/ j.ieri.2012. 06.099.

[11] Enqvist M, Gunnarsson S, Norrlöf M, et al. The CDIO initiative from an automatic control project course perspective, IFAC Proceedings Volumes, 2005: pp.67-72. DOI: 10.3182 /20050703-6-CZ -1902 .02284

[12] YUAN Xuemei, LIU Jia, MA Qian, et al. Practical Teaching Mode of Military Operations Research Course Based on CDIO Concept, in Journal of Military Transportation University, 2020, 22(7), pp. 75-78. 
[13] M. Koehler, P. Mishra, W.Cain, What Is Technological Pedagogical Content Knowledge (TPACK)? in Journal of Education, Boston, vol. 193, pp.13-19, 2013.

[14] L.Shulman, Those Who Understand: Knowledge Growth in Teaching, in Educational Researcher, vol. 15, pp. 4-14, 1986.
[15] Chung-Jen Wang. Facilitating the emotional intelligence development of students: Use of technological pedagogical content knowledge (TPACK), Journal of Hospitality, Leisure, Sport \& Tourism Education, vol.25, p. 100198, 2019. DOI:10.1016/j.jhlste.2019.100198. 